\title{
2093 CMR reveals that cardiac-specific overexpression of the inducible form of nitric oxide synthase induces Left Ventricular Hypertrophy in wild-type mice after AAV-Mediated direct gene transfer
}

\author{
Konkal MR Prasad, Ronald J Beyers, Yaqin Xu, Frederick H Epstein and \\ Brent A French*
}

Address: University of Virginia, Charlottesville, VA, USA

* Corresponding author

from I th Annual SCMR Scientific Sessions

Los Angeles, CA, USA. I-3 February 2008

Published: 22 October 2008

Journal of Cardiovascular Magnetic Resonance 2008, I0(Suppl I):A362 doi:10.I I86/I532-429X-I0-SI-A362

This abstract is available from: http://jcmr-online.com/content/I0/SI/A362

(c) 2008 Prasad et al; licensee BioMed Central Ltd.

\section{Introduction}

CMR has previously shown that left ventricular remodeling (LVR) resulting from reperfused myocardial infarction (MI) is dramatically reduced in iNOS knock-out mice [1]. However, previous studies using transgenic mice with cardiac-specific overexpression of iNOS have yielded disparate results. One study reported a benign phenotype while a second reported that iNOS overexpression resulted in cardiac fibrosis, hypertrophy and dilatation. One explanation is that transgenic mice may develop compensatory mechanisms to down-regulate iNOS overexpression. Another possiblity is that the phenotype of iNOS overexpression may be variable in its penetrance due to limited availability of a necessary co-factor (tetrahydrobiopterin).

\section{Purpose}

To overcome these limitations, our laboratory modified a highly-efficient gene transfer system to achieve cardiacspecific iNOS expression after a single IV injection. The resulting mice were treated with the natural precursor of tetrahydrobiopterin (sepiapterin) and CMR was performed to assess the impact of iNOS overexpression on LV form and function.

\section{Methods}

High-efficiency, cardiac-specific gene transfer was achieved by using a cardiac-specific troponin $\mathrm{T}$ ( $\mathrm{cTnT}$ ) promoter in an adeno-associated viral (AAV) genome packaged into an AAV9 capsid. Thus the CDNA for murine iNOS was subcloned behind the cTnT promoter in an AAV-generating plasmid and packaged into AAV9 capsids using a system kindly provided by Dr. James M. Wilson (U. Penn, PA) to create AcTnTiNOS. The resulting viral particles were purified and viral titers were determined as genomic particles $/ \mathrm{ml}$ by real-time PCR. A total of twelve $\mathrm{C} 57 \mathrm{Bl} / 6$ mice were used. Three were injected via jugular vein with increasing doses of AcTnTiNOS for Western blot analysis at 4 weeks post-injection. Four mice were similarly injected with $1 \mathrm{E}+11$ AcTnTiNOS particles at 4 weeks of age for CMR analysis. Starting 10 weeks after vector injection, these mice were additionally treated for 4 weeks with sepiapterin $(50 \mu \mathrm{g} /$ day by Alzet micro-osmotic pump). Another 5 untreated $\mathrm{C} 57 \mathrm{Bl} / 6$ mice served as agematched controls. CMR was performed at the end of sepiapterin treatment to assess the impact of iNOS overexpression using a $4.7 \mathrm{~T}$ Varian system and a black-blood pulse sequence as described [2]. Excised hearts from the control and AcTnTiNOS-treated groups were immunostained for iNOS and for cleaved caspase III (a sensitive marker of apoptosis). 


\section{Results}

Western blots revealed dose-dependent increases in iNOS protein in the hearts of mice injected 4 weeks earlier with AcTnTiNOS (Figure 1C). No iNOS protein was detected in other tissues from the same mice, or in any tissue from control mice. The results of CMR analysis revealed no significant differences between the two groups in: body mass, LV end-diastolic volume, end-systolic volume, stroke volume, ejection fraction, heart rate, cardiac output or LV mass to volume ratios. However, significant differences $(\mathrm{p}<0.05)$ did exist between the control group (Figure $1 \mathrm{~B}$ ) and the AcTnTiNOS-treated group (Figure 1C) in both LV mass ( $57+/-2$ vs. $65+/-2 \mathrm{mg}$ ) and LV mass index $(3.2+/-0.1$ vs. $3.4+/-0.1$, respectively). Abundant iNOS was detected by immunohistochemistry in $>90 \%$ of AcTnTiNOS-treated cardiomyocytes, whereas no iNOS staining was evident in the hearts of control mice. Similarly, apoptosis (i.e., cleaved caspase III) was readily detected in AcTnTiNOS-treated cardiomyocytes, whereas essentially no cleaved caspase III was found in control cardiomyocytes (Figure 1D and 1E).

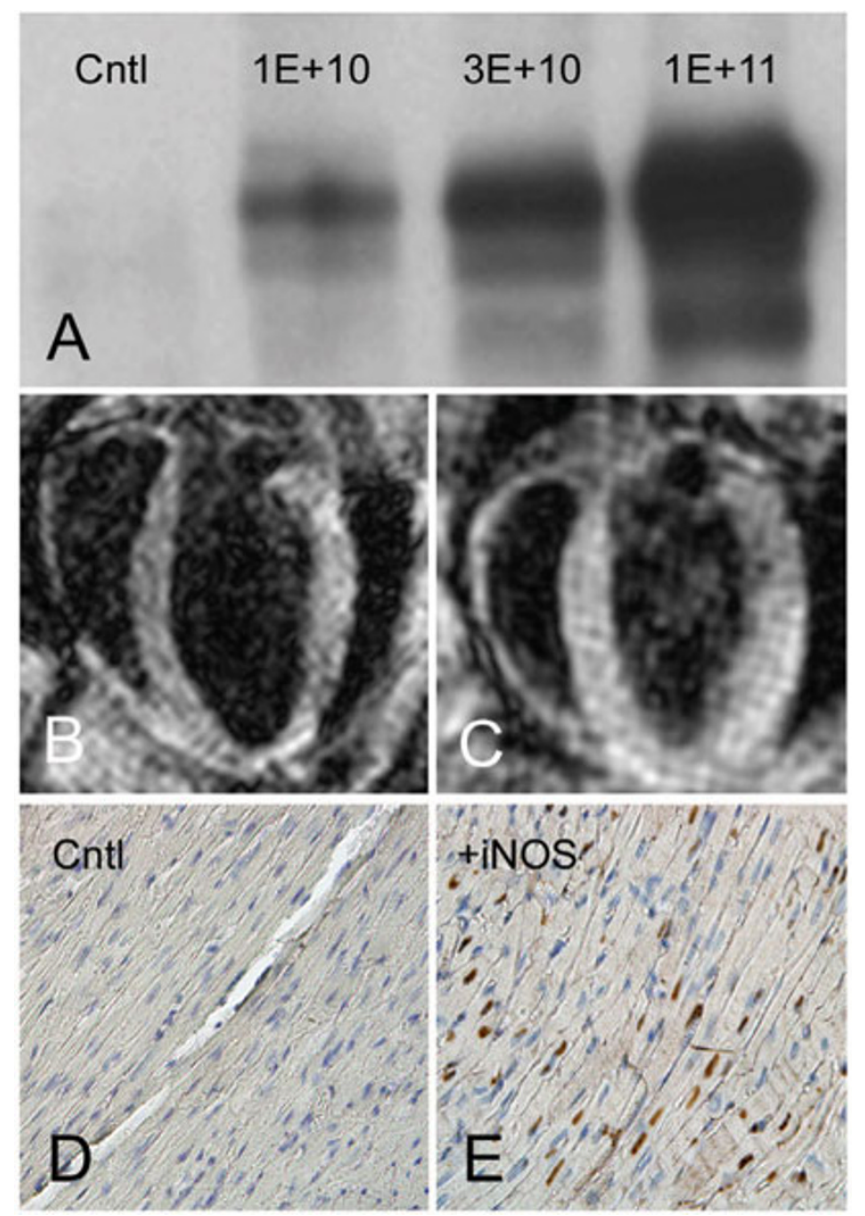

Figure I

\section{Conclusion}

This study demonstrates that gene expression from AAV vectors can be restricted to the heart, that gene expression persists for over 3 months, and that high-levels of cardiac iNOS lead to apoptosis and significant LV hypertrophy. More generally, this study demonstrates (for the first time) that cardiac-restricted, direct gene transfer with AAV vectors can be used in conjunction with CMR to determine the function of individual genes in the hearts of intact mammals.

\section{References}

I. Gilson WD, et al:: JACC 2007 in press.

2. Berr SS, et al.: MRM 2005, 53(5): I074-9.
Publish with Biomed Central and every scientist can read your work free of charge

"BioMed Central will be the most significant development for disseminating the results of biomedical research in our lifetime. " Sir Paul Nurse, Cancer Research UK

Your research papers will be:

- available free of charge to the entire biomedical community

- peer reviewed and published immediately upon acceptance

- cited in PubMed and archived on PubMed Central

- yours - you keep the copyright

Submit your manuscript here:

http://www.biomedcentral.com/info/publishing_adv.asp
BioMedcentral 